\title{
ANALYSIS OF FOREIGN DIRECT INVESTMENTS AND ITS' IMPACT ON RESTRUCTURING OF LITHUANIAN ECONOMY
}

\author{
Manuela Tvaronavičiené1, Romualdas Ginevičius ${ }^{2}$ \\ Vilnius Gediminas Technical University, Saulètekio al. 11, LT-2040 Vilnius, Lithuania, \\ e-mail: manuela@post.omnitel.net, ${ }^{1}$ rector@adm.vtu.lt ${ }^{2}$
}

Received: 14 February, 2003

\begin{abstract}
The paper deals with foreign direct investments (FDI) in Lithuania. An issue of priority is to determine if inflow of foreign capital in all cases contributes sufficiently to development of national economy. Investigation of controversial impact of FDI on Lithuania is based on theories presented by concise review of the literature examining the role of FDI in transition economies. The detailed analysis of FDI directed to different sectors of Lithuanian economy let to determine cases when globalization retards economic development of host country.
\end{abstract}

Keywords: globalization, foreign direct investments, economic growth, privatization, restructuring of economy, motivation of investors, quantitative evaluation.

\section{Introduction}

In the context of European Union enlargement and economic restructuring of national economies transition countries usually see inflow of foreign capital as an issue of priority. Such an approach to FDI, as a rule, dictates appropriate policy of government directed to providing of various stimuli to foreign investors. Meanwhile, certain cases raise doubts if globalization unconditionally guaranties growth of productivity, increase of quantity and quality of provided goods and services.

Presented analysis of FDI in Lithuania is aimed to segment inflows of foreign capital and quantitatively evaluate impact of different investments on growth of Lithuanian economy. Analysis of segmented by sectors of economy FDI in Lithuania would let to identify cases when globalization represent certain risk for transition countries.

\section{Theoretical background of analysis}

Theoretical discussion concerning impact of FDI on host country economy focuses on whether globalization of foreign enterprises contributes or retards development of local economic entities.

Positive approach to globalization is dictated by a most cited possibility that FDI generates productivity spillovers for the host economy [1]. One idea is that multinational enterprises possess superior production technology and management techniques, some of which are captured by local firms when multinationals locate in a particular economy. A related source of spillovers is forward and backward linkages between multinational and host-economy firms [2], which may result from multinationals providing inputs at lower cost to local buyers or by their increased demand for inputs produced by local suppliers. Despite spillovers are key factor supporting positive impact of globalization, but their existence and magnitude difficult to establish empirically.

Negative approach to globalization is represented by view, according which multinationals mostly are oligopolistic companies, locating in protected markets with high barriers to entry and increasing market concentration. They extract rent, shiphon off capital 
through preferred access to local capital markets, and drive domestic producers out of business [3]. To continue presented view we could add, that special favorable conditions guarantied by high barriers of entry don't encourage increase of productivity in terms of increased quality or volume of production. That finally means that globalization in such a case don't contribute sufficiently to development of host country economy. Despite presented view is more characteristic for earlier researchers, as we will show later it still can be attributed to very topical issues.

To summarize key results of the literature on globalization impact on host country economy, we have seen that in theory FDI impacts national welfare in two diametrically opposite directions: on the one hand it raises the productivity of domestic economy but, on the other hand, it drives domestic producers out of market, endeavors favorable uncompetitive position in the market, which can lead to appropriate loses conditioned characteristic by monopoly.

Controversially evaluated role of cross-border capital flows dictated the angle of presented investigation. The assumption has been made: the composition of capital flows finally dictates impact of FDI on development of national economy. Hence, it's composition of FDI by sectors of economy and magnitude of investments, what ultimately matters, when impact of globalization is scrutinized.

\section{Methodology of research}

In quantitative terms economic growth the most accurately could be expressed through increase of volume of produced goods and services provided during specific period of time, or to put it into another words, though increase of Gross Domestic Product (GDP). Aiming to evaluate impact of segmented foreign capital inflows on growth of host economy the following approach has been adopted. A premise has been made that the correlation between GDP and separate inflows FDI, expressed as percentage share of total FDI directed the country, represent a most accurate measure of efficiency of globalization of separate sectors of economy. Hence, in presented paper emphasis has been put on percentage composition of FDI rather than on absolute values of FDI expressed in monetary terms. Such approach finally lets to take into account change in magnitude of FDI flows directed to certain sectors of economy, when absolute value of the same indicator doesn't provide possibility to focus on impact of dissemination of FDI on national economy. Finally, concentration on FDI structure leads to comparison of it to present structure of GDP by economic sectors, and, consequently, to prediction of future trends of restructuring economy of host country.

\section{Analysis of FDI tendencies in Lithuania}

Foreign Direct Investments according methodic of International Monetary Fund (Detail Benchmark Definition Foreign Direct Investment) are such investments on basis of which long-term relationships and interests between FDI investor and host enterprise have being formed [4]. Limit of 10 and more percent of common process of management of enterprise-recipient of capital. Hence, only investments exceeding the pointed out limit are considered as foreign direct investments and represent target of our investigation. Characterizing definition of FDI, it should be noted, that criteria applicable to FDI identification don't involve aspects related with mode of investments have been made. Hence, "green field" investments in these terms have been equalized to privatization revenues, what from the point of view of economic grow, the most probably, will generate quite different effect.

There could be distinguished three stages of globalization process in Lithuania. The first stage continued till 1991, the second lasted from 1991 to 1996, and the third stage has started in 1996. The laws regulating processes of globalization in Lithuania have been adopted comparatively later than in other transition countries. This factor is considered to be not of the least importance when trying to identify main reasons of globalization tendencies presented below.

Hence, the more significant inflow of foreign capital started only Lithuania regained its independence in 1990. In this year economic reform started and the main laws regulating economic activity in market conditions were adopted. This point in time is held as the actual beginning of transition and globalization processes. Notably, that in year 1991 it was recorded seven times more joint ventures than during three previous years and FDI reached $32 \mathrm{mln}$. Litas. During the very first years of transition rate of FDI growth was insignificant, most probably due to instable economic situation on country: the first years of independence were characterized by high inflation, series of bank crises, vague conceptions of future economic reform etc. Situation gradually improved and in year 1994 completely stabilized. Therefore we have chosen this year as initial point for our more thorough analysis of FDI tendencies.

Since 1994 speeding up economical reform, growing GDP and more stable economical environment measured by significantly reduced rates of inflation played 


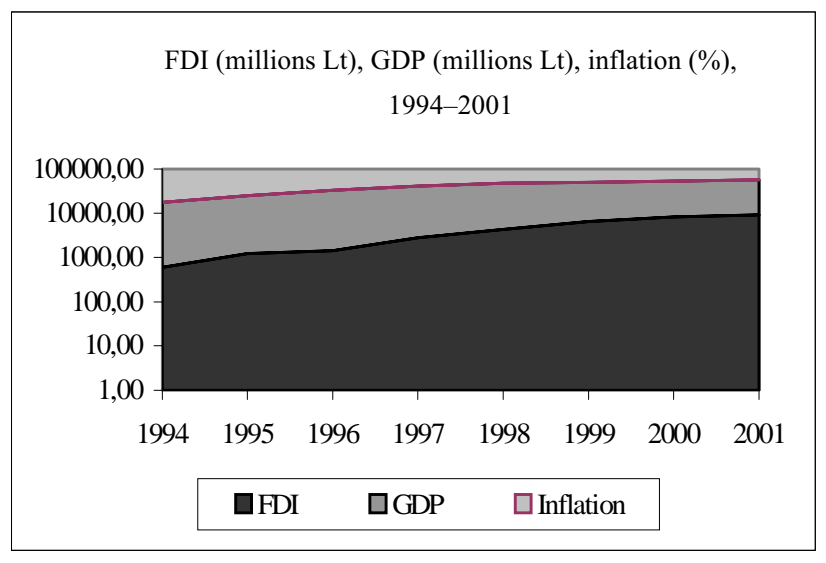

Fig. 1. FDI, GDP and inflation dynamics in 1994-2001

key role in attracting foreign capital into country (Figure 1). Intensive privatization stood for the main form of foreign investment and could be identified as one of the most important channels of FDI inflows.

More close view to FDI dynamics in Lithuania leads to observation that the major part of interested in globalization foreign firms entered market of the host country during the first several years after independence regaining. According poll organized by Lithuanian Development Agency [5], e.g. in 1996 more than $60 \%$ of new FDI were made by investors, who were increasing scale of their activity in Lithuania, i.e. only $40 \%$ of capital inflows came from new foreign firms. Scrutinizing process of globalization in numerical terms we have to emphasize that in 1998 total amount of foreign capital flows equaled to one, which was directed to Lithuania during a whole period from 1994 to 1997 , and up to year 2001 FDI increase compared with 1996 was several times greater. Again, privatization in years of higher FDI played rather important role in attracting capital flows.

Final target of presented investigation is to determine if inflow of foreign capital in all cases contributes sufficiently to development of national economy. Such approach to globalization efficiency requires detailed analysis of FDI composition by different sectors of economy. Detailed analysis of FDI composition should start from identification of main targets of interest of foreign investors. Lithuanian GDP structure by sectors of economy (Appendix 1) lets to distinguish four main branches of Lithuanian economy: services, industry, agriculture and construction.

Close look to FDI structure (Figure 2) reveals that foreign investors have found those branches of Lithuanian economy not equally attractive.

Distribution of FDI among main for Lithuania sectors

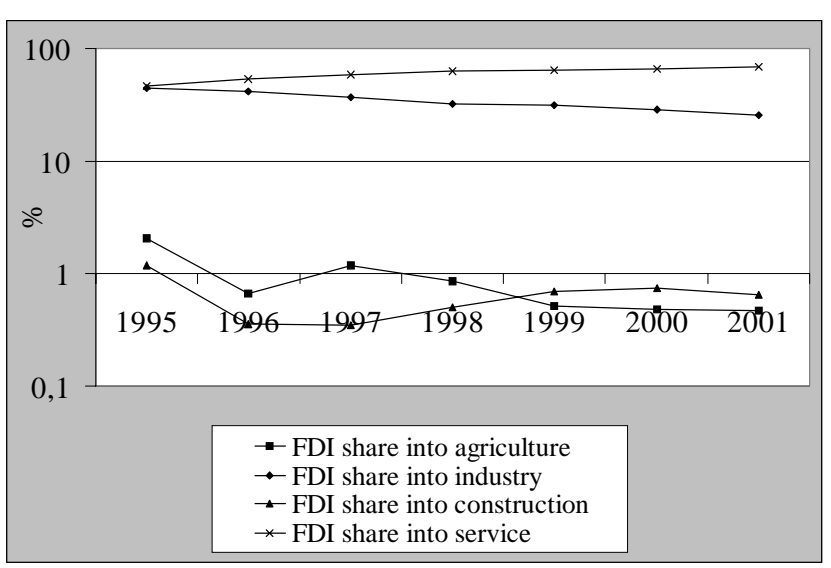

Fig. 2. FDI structure by main sectors of Lithuanian economy in 1995-2001, \%

of economy has been quite uneven. As we see, foreign investors have expressed obvious interest in service sector. Notable, that comparatively higher investment into services vis-ą-vis production corresponds to tendencies of global economy: in many countries structure of economies shifts towards services sectors. In Lithuania percentage share of FDI put into service sector in 1995-2001 increased from $47.95 \%$ to $66.0 \%$. Especially increased FDI share directed to financial intermediation (Figure 3). Privatization of Lithuanian Savings Bank and Agricultural Bank significantly contributed to latter increase of FDI share.

Telecommunication sector also attracted comparatively high FDI. Privatization of such public monopoly as Lithuanian Telecom and intensive development of mobile communication have conditioned significant inflows of foreign capital. "Green field" investments have been more characteristic for wholesale and

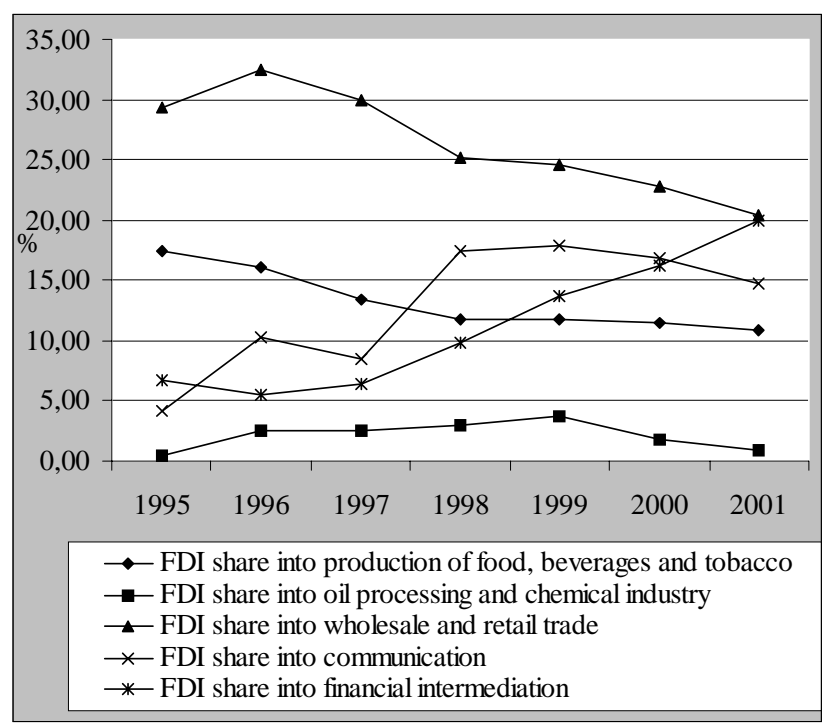

Fig. 3. FDI percentage distribution among the major types of Lithuania economic activities 
retail trade sector (in figure 3 dynamics of FDI into main activities of interest comprising service and industry sectors is presented).

Inflows of FDI into industry sector in 1995-2001, in contrary, diminished from 44.13 to $28.0 \%$. Foreign investors expressed interest in food, especially milk, processing, electronics, electrotechnics, light, chemical and oil processing industries. Nevertheless, the major part of investments in this sector has been directed into food processing, while interest in other activities was rather vague (Figure 3).

As concerns such important for Lithuania sectors of economy as agriculture and construction, they, alas, as it has been shown in Figure 1, attracted comparatively small capital inflows: share of FDI to each sector during period of 1995-2001fluctuated about 1\%.

Agricultural sector historically has played very important role in Lithuanian economy. Now it comprises only $6 \%$ of GDP, but in this sector more than $21 \%$ of labor force is engaged. Hence, obvious low productivity of agricultural sector remains an urgent issue. Lack of interest from the side of foreign investors means that Lithuanian situation continue to be quite complicated and have to be improved by engaging local scare resources. Joining EU with all restrictions and regulations and high competitiveness in agricultural sector even more sharpens question of dealing with unproductive sector.

Analysis of composition of capital inflows of foreign capital showed that it doesn't correspond to composition of GDP. That means that FDI finally conditions restructuring of national economy. Tendencies of GDP restructuring (Figure 4) in principle correspond to FDI dynamics what lets look at globalization processes as one of the main factor determining shifts in composition of national economy.

The question, how globalization of separate sectors of

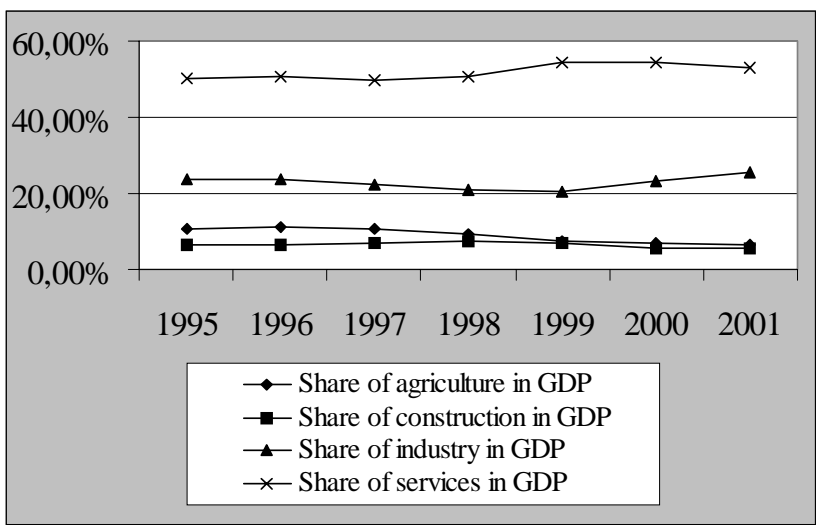

Fig. 4. Dynamics of GDP percentage distribution on economic activities during 1995-2001 economy impacts growth of general welfare of host country, remains key target of presented investigation. Below we present quantitative evaluation of influence of separate inflows of FDI on GDP growth and comparison of FDI and GDP structure, what lets to identify sectors in which foreign capital reached the highest level of penetration.

\section{Quantitative evaluation of FDI efficiency}

Quantitative evaluation of impact of separate foreign capital inflows on growth of national economy is very important as results would let to reveal certain cases and circumstances in which globalization represents threat to growth of national economy, and therefore should be prevented rather than stimulated by local government.

We repeatedly emphasize that, despite the majority of politicians and economists point to the positive sides of globalization, it doesn't mean, as it has been shown in scientific literature review, that each capital inflow finally stimulate economic growth. Our investigation tends to identify how FDI structure conditioned by objective factors (such as costs of production, level of consumption) and subjective ones (economical policy) affects GDP. Strength and direction of relationship between FDI structure and GDP would present direct answer to the question about efficiency of FDI directed to the different sectors of economy.

Method of correlation-regression analysis has been chosen for quantitative evaluation of FDI efficiency. Application of it lets to determine type of relationship between GDP and FDI flows into separate sectors of economy. Value of correlation coefficient nearing to 1 indicates that relationship between variables is strong, and sign of correlation coefficient - negative or positive - shows if, in our case, considered FDI flows negatively or positively effect economic growth. Data used for calculations and results presented in Appendix 2.

At the first stage of economic interpretation of calculation results lets concentrate on relationship between FDI into main sectors of Lithuanian economy (Figure 2) and GDP. Correlation coefficient between FDI share to agriculture and GDP is negative $(-0.81)$ and insignificant. That lets to state that specific and unfavorable business environment conditioned low and, even more, diminishing share of FDI (during period 19952001 it diminished from 2.06 to $0.47 \%$ ), and contraction of this sector (in 1995-2001 sector contracted from 10.7 to $6.9 \%$ ). Hence, conclusion is that FDI to agriculture in Lithuanian case doesn't affect properly 
growth of GDP. Very similar interrelation between FDI to construction and GDP was found: here correlation coefficient also is negative and insignificant (it equals to 0.37 ).

Considering insignificant values of correlation coefficients between FDI share to agriculture and construction, in the further analysis we will put emphasis on FDI into services and industry, which in 2001 both together comprised $95 \%$ of total amount of foreign capital inflows. Interrelationship between FDI into those sectors and GDP is strong and significant: correlation coefficient between FDI share into services and FDI is equal to 0.99 , and between FDI to industry and GDP accordingly equals to -0.814 .

Hence, application of mathematical method confirmed theoretical premise about controversial impact of globalization of separate sectors on economical growth. In our case we received negative relationship between FDI share directed to industry and GDP, what indicated that globalization of industry sector retards development of economy. This aspect we will scrutinize thoroughly below.

A multidimensional linear equation lets to evaluate quantitatively impact of FDI shares directed to services and industry on GDP growth (determination coefficient of the equation $99 \%$, what confirms reliability of calculations):

$\mathrm{GDP}=-23217,08-31,27 \times \mathrm{X}_{1}+1044,57 \times \mathrm{X}_{2}$;

here: $X_{1}-$ FDI share into industry;

$X_{2}-$ FDI share into services.

Presented equation indicates that FDI distribution between sectors of economy plays quite important role in stimulation of GDP growth. The following comments could be brought. Positive strong relationship between share of FDI into service sector and GDP could be conditioned by increasing inflows of capital into this sector. Now it accumulates $69.0 \%$ of all FDI, what contributes to development of the sector and increasing share it comprises in GDP (now service share in GDP reached 54.3\%). Generalizing we can conclude, that globalization of service sector is efficient from the point of view of host economy. Converse result characterizing impact of FDI share into industry on GDP could be partially caused by contraction tendencies of industry sector (during period 1995-2001 share of industry in GDP fluctuated from 23.9 to $25.6 \%$, but in year 1999 it contracted up to $20.4 \%$ ). Contraction of industry sector could be due displacement of local firms out of the market by foreign players or due to globalization processes of monopolistic firms, what objectively don't properly contribute to growth of GDP.

Evaluation of globalization efficiency in service and industry sectors should be done taking into account variety of activities, which have been embraced by considered sectors. Hence, the final conclusions about efficiency of separate inflows of foreign capital could be drawn only after scrutinizing relationships between FDI into those partial activities and GDP. Further analysis would involve two steps. At first, determination of relationship type between GDP and FDI shares into separate service activities would be done, and, the second, the same between GDP and FDI into main industry branches would be repeated. Interpretation of the results would provide quite accurate evaluation of different facets of globalization.

We will concentrate on activities, which attracted the most significant capital inflows. In service sector the following ones could be distinguished: wholesale and retail trade $(20.4 \%$ of $\mathrm{FDI})$, financial intermediation (19.9\% of FDI), and communication (14.8\% of FDI). Statistical data on FDI distribution according economical activities presented in Appendix 2. Using the data pair correlation coefficients have been determined. However, Student coefficients signalized that FDI share taken separately into each considered activity doesn't affect GDP. Application of multidimensional correlation analysis let to receive linear equation showing impact of all service activities (even including not very significant ones) on economical development:

$$
\begin{aligned}
& \text { GDP }=1203127,74-34741,80 \times X_{1}+475482,26 \\
& \times X_{2}-122875,01 \times X_{3}-83112,72 \times X_{4}+58419,61 \\
& \times X_{5}-41301,91 * X_{6}-475433,89 \times X_{7}
\end{aligned}
$$

here: $X_{1}$ - FDI share into wholesale and retail trade; $X_{2}$ - FDI share into hotel and restaurant activity;

$X_{3}$ - FDI share into transportation activity;

$X_{4}$ - FDI share into communication;

$X_{5}$ - FDI share into financial intermediation;

$X_{6}$ - FDI share into real estate;

$X_{7}$ - FDI share into education, health care, leisure and culture.

Presented multidimensional correlation equation enabled to reveal quite controversial from the superficial sight relationships. According the equation, relationship between FDI share directed into trade and GDP is negative, what could seem hardly possible. Nevertheless, closer look into considered activity provides appropriate explanation to the negative relationship. Share of trade in GDP is quite significant, but it have been diminishing: e.g. while in 1995 it comprised 
$16.3 \%$ of GDP, in 2001 share of trade contracted to $13.9 \%$ of GDP. Despite that this activity attracts quite big share of foreign capital inflows (in year 2001 up to $20.4 \%$ ), attractiveness of it seems to be decreasing: in 1995 trade attracted $29.4 \%$ of FDI, while in 2001 accordingly 20.4\%). Specifics of Lithuania suggest the following interpretation. FDI have reached such "saturation" of activity, which due to limited purchasing capacity makes further investment economically inefficient. Instead of increase in volume of sales additional investment started to lead only to redistribution of existing market share and to displacement of comparatively weaker firms. Hence, increase in FDI share wouldn't mean increase in GDP. FDI into trade activity diminishes, GDP, in general, grows, what conditions negative relationship between FDI into trade and GDP. Listed above arguments leads to a conclusion that here foreign capital reached high concentration and replaced local players.

Investigation also indicates negative relationship between GDP and FDI share into communication. Contrary than in trade activity, FDI share during considered period has been increasing and, at superficial glance, should positively impact GDP growth. Negative relationship could be caused by FDI, which had come via privatization of very important object for Lithuania - Lithuanian Telecom. Monopolistic position of privatized Telecom conditioned favorable uncompetitive situation in providing of fixed telecommunication service. It is notorious, that regulation of public monopoly is comparatively easier task than regulation of private monopoly. Hence, privatized Telecom, being private monopoly considerably increased prices, what, in its turn, caused some loss of consumers and decrease in volume of services provided, but, at the same time Telecom's revenues haven't diminished. In this case globalization in principle started to retard development of all sector of communication. This tendency of slowing down of development has been partially neutralized by sharp increase in demand of mobile communication [6]. Finally, we need to admit that Lithuanian case of globalization of telecommunication sector confirms theory about certain jeopardy to host country from the side of multinationals located in protected markets.

Notable, that some negative tendencies, traced in activity of Lithuanian Telecom, share of whole communication sector in GDP has been growing, and in 1998-2001 increased from 8.5 up $11.1 \%$. Growth of sector has been reached due to increasing of activity scale of such foreign capital mobile companies as Omnitel, Bite GSM, Tele-2 : e.g. revenue of Omnitel during only year 2001 increased by $44.4 \%$, Bite GSM managed to grow almost at the same extent (Lithuanian Bank, 2001). Growth in sales and constantly decreasing prices witness, that competitive environment in mobile telecommunication activity leads to increase of efficiency. Hence, we encountered situation when different capital flows into the same - telecommunication - sector of activity controversially impact development of national economy. Foreign capital flows directed into Lithuanian Telecom exceeded all other FDI into sector, what, finally determined negative impact of FDI share in communication on GDP.

Results of presented above multidimensional correlation equation indicate that FDI share into financial intermediation initiates development of this branch and contributes to GDP growth. It is peculiar, that foreign capital into the sector flew through different channels, among which privatization wasn't prevailing one. In 2001 Lithuanian Savings Bank was privatized. Differently, compared to Lithuanian Telecom, this bank didn't occupy monopolistic positions and its financial results were far from the leading banks. Even more, after privatization in result of reevaluation of material assets expenses increased by 85.5 million litas, what indicated that Lithuanian Savings Bank actually worked at a loss [6]. Hence, inflow of foreign capital through privatization in this sector didn't provide favorable conditions for investors. Additional FDI came to Vilnius Bank and Hansa Bank (previous Lithuanian Savings Bank) through channels not related to privatization. Financial intermediation sector started slightly to grow in year 2000. The growth was caused such factors as globalization and increase in demand in services of insurance companies due to introduction of compulsory civil insurance of cars. Nevertheless, globalization in sector of financial intermediation played the most important role in strengthening of key players and contributed to development of national economy.

Close look into globalization of service sector revealed that, despite, FDI share into services, in general, initiates development of national economy, separate capital flows retard economic growth of Lithuania. The most positive effect has foreign investments into financial intermediation, and the most negative effect have been traced in sphere of communication.

The following step of analysis will involve analogical determination of relationship type between GDP and FDI shares into main industry branches. Interpretation of the results would provide evaluation of different aspects of globalization in industry of Lithuania. 
For detail analysis have been chosen those branches of industry, which, from the one side, attracted the major share of FDI, and, from the other side, have been considered as being of prime importance for Lithuanian economy. Received, and selected according Student coefficient (Appendix 2), correlation coefficients indicated that GDP is mostly effected by globalization of following branches of industry: processing of food, refining of oil and chemical industry, production of rubber plastic items, production of electrical and optical equipment. The extent and direction of interrelation between FDI share into listed activities and GDP is presented by received multidimensional correlation equation (determination coefficient $99 \%$, what means that equation is significant:

$\mathrm{GDP}=79566.68-2144.11 \times \mathrm{X}_{1}-598.20 \times \mathrm{X}_{2}-$ $4666.23 \times \mathrm{X}_{3}-1488.17 \times \mathrm{X}_{4}$

Here: $X_{1}$ - FDI share into food processing industry;

$X_{2}-$ FDI share into oil refining and chemical industry;

$X_{3}$ - FDI share into production of rubber and plastic items;

$X_{4}$ - FDI share into production of electrical and optical equipment.

Calculations verify that globalization of industry don't initiate growth of economy enough, despite this sector of economy attracts significant share of FDI. Meanwhile, statistical data indicate recovery of food processing and other industries as increase of productivity and volumes of production were recorded [7]. Negative impact on economic development of country obviously had losses of such privatized strategic object as Mazeikiu Oil Refinery, which during period 1998-1999 increased from 32272 thousand litas to 134552 thousand litas. That confirms that globalization of monopolies, especially retard economic growth.

Investigation showed that globalization process of monopolies in Lithuania take place mainly through privatization. Privatization policy directed to so called "strategic investors" in principle conditions further restriction of competition in industries characterized by high concentration and big barriers of entry. Later on privatized enterprises enjoy favorable business conditions and aren't orientated enough to increasing of efficiency. Hence, government policy in field of regulation of globalization processes should put emphases on complex of economic tools making "green field" investments more attracting for foreign investors.

Evaluation of globalization process would be more thorough if FDI impact on restructuring of economy was taken into account. Hence, below globalization level of separate branches of economy will be scrutinized.

\section{Impact of FDI on restructuring of Lithuanian economy}

Impact of globalization on Lithuanian economy could be analyzed from another point of view. Comparison of FDI distribution between various sectors of economics and economical activities, from the one side, and GDP structure, from the other side, would let to indicate main directions of restructuring of national economy conditioned by globalization processes. We propose to perform the comparison by calculation ratio of percentage share of FDI directed into certain activity and percentage share of GDP generated by considered activity. If calculated ratio is greater than 1 that means, that appropriate activity attracts comparatively more foreign capital flows and, therefore, is more saturated by foreign capital. If globalization of considered sector, according presented above analysis, positively impacts GDP, then in the future the sector will be developed more rapidly. In Figure $5 \mathrm{dy}-$ namics of ratio reflecting comparison of FDI and GDP structure is presented.

The highest values of ratio were recorded in such activities as trade, industry and, especially, financial intermediation. Considering results of performed

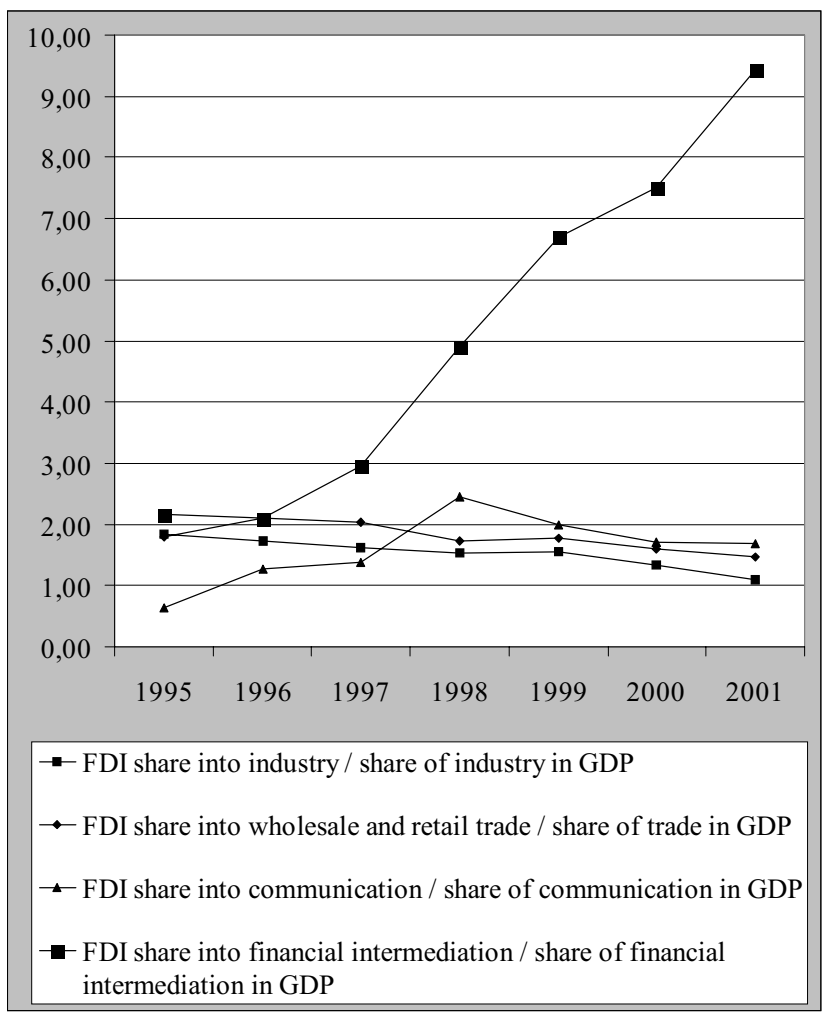

Fig. 5 Dynamics of ratio reflecting comparison of FDI and GDP structure during 1995-2001 
analysis we can expect that globalization processes will especially condition expansion of financial intermediation sector.

Probability that economy will be restructured towards trade and industry is treated as being quite insignificant as doubtful impact of FDI into those sectors on GDP growth has been determined.

Analysis of globalization processes in transition countries should involve especial emphasis on privatization processes. Pure fact of privatization couldn't be treated nor positively neither negatively. Meanwhile, occupation of monopolistic position by foreign investor doesn't lead to increase of efficiency and, as investigation show, finally negatively impact development of host economy.

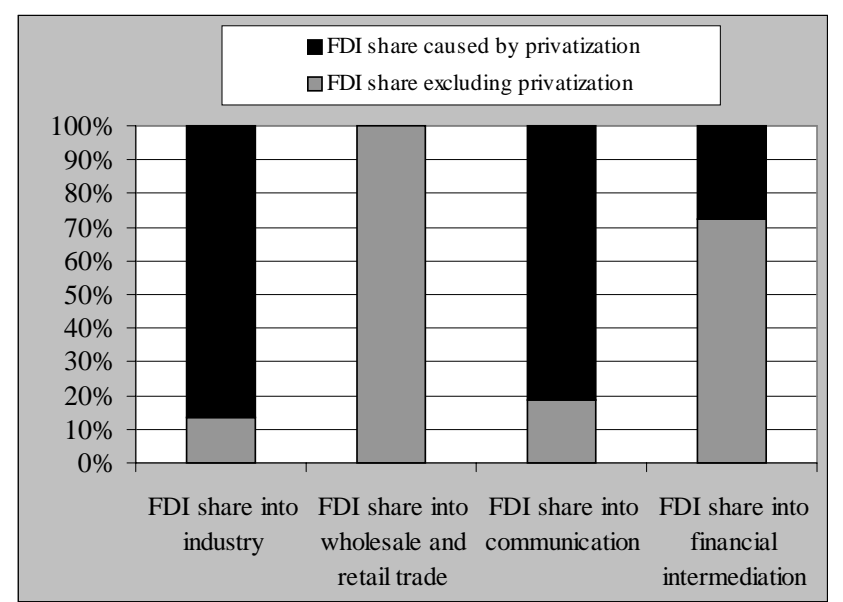

Fig. 6. Sources of FDI into main economic activities

Basing on poll of the biggest firms of foreign capital (Appendix 3) performed by Institute of Free Market Economy (The biggest investors) analysis of FDI sources has been done (Figure 6).

Results of current analysis indicate that in those sectors, in which significant share of FDI came via privatization, the most probable outcome of globalization is negative (in Lithuania in two out of three cases, where privatization played important role - in industry and communication sector - globalization results have been evaluated as negative). Foreign capital inflows reached country through other channels better impact growth of national economy.

\section{Conclusions}

1. Review of economical literature leads to conclusions that impact of FDI on development of economy of host country could be different and, even, quite controversial. In one case globaliza- tion can initiate growth of GDP through increase in quality and quantity of goods produced and services provided. It conditions spillover of knowledge, technologies experience to local companies, what enable them to survive even in environment of increased competition. In another case, globalization in sectors with high barriers of entry can enjoy favorable business conditions, extract rent and replace local economical entities out of market.

2. Performed economical analysis revealed that in Lithuania globalization of service sector positively impact economical growth, while globalization of industry sector doesn't.

3. Investigation has led to corollary that positive and negative impact of globalization is concurrent. Some inflows of foreign capital into the same sector of economy can be efficient from the point of view of host country, and some not. In transition countries, negative result of globalization most probably will be traced in privatized monopolies.

4. Generalizing Lithuanian case it should be stated that the highest level of globalization has been determined in trade, financial intermediation and industry. In some cases replacement of local firms took place, what confirms theoretical premises about malign impact of globalization.

5. Globalization process effects restructuring of national economy. Considering results of performed analysis we can expect that in the future sector of financial intermediation will expand significantly.

6. Despite overall effect of globalization is positive, government of transition country should more responsibly form privatization policy and put more emphasis on "green field" investments.

\section{Summary}

The paper deals with foreign direct investments (FDI) in Lithuania. The following question is scrutinized: does international capital always initiate the development of national economy.

Two alternative approaches to the impact of globalization on host-country economy can be found. The first suggests that foreign direct investments may help to speed up the process of industrial development helping to increase the productivity of local enterprise, while the second grounds the plausibility of a quite negative impact of globalization on economies of host countries.

The presented paper is based on the following 
approach of the evaluation of an impact of globalization on the efficiency of functioning economic entities. The assumption has been made that a correlation analysis of FDI structure into the main branches of industries and GDP of Lithuania should show if the inflow of foreign capital has a positive or a negative effect on the development of national economy. The results permit to reveal the specifics of interests of foreign investors and lead to adequate suggestions concerning policy implications.

Investigation let to reveal that in practice positive and negative impact of globalization is concurrent. Some inflows of foreign capital into the same sector of economy can be efficient from the point of view of host country, and some not. In transition countries, negative result of globalization most probably will be traced in privatized monopolies.

Generalizing Lithuanian case it should be stated that the highest level of globalization has been determined in trade, financial intermediation and industry. Performed economical analysis indicated that in Lithuania globalization of service sector positively impact economical growth. Nevertheless, separate capital flows into some activities belonging to service sector retard economic growth. The most positive effect has foreign investments into financial intermediation, and the most negative effect have been traced in sphere of communication. Globalization of industry sector doesn't have positive impact on development of economy of host country.
Globalization process effects restructuring of national economy. Considering results of performed analysis we can expect that in the future sector of financial intermediation will expand significantly.

Despite overall effect of globalization is positive, government of transition country should more responsibly form privatization policy and place more emphasis on "green field" investments.

\section{Literature}

1. Blomstrom M. and Kokko A. (1998). Multinational corporations and spillovers. Journal of Economic Surveys, 12, p. 247-277.

2. Rodriguez-Clare A. (1996). Multinationals, linkages and economic development. American Economic Review, 86, p. 852-873.

3. Brecher, R. and Carlos Diaz-Alejandro (1977). Tariffs, Foreign Capital, and Emerging Growth. Journal of International Economics, Vol. 7, p. 317-322.

4. Report on the Methodological Standards for Direct Investment. International Monetary Fund, 1999.

5. Lithuanian, Latvian, Estonian Development Agency (2001), http://www.lda.gov.lt

6. Review of Lithuanian macroeconomics. Vilnius Bank, Vol. 4, 6, 9. Vilnius, 2001.

7. Lithuanian statistical yearbook, 2002. Department of statistics. Vilnius, 2002.

8. The biggest investors in Lithuania. http://www.lda.lt 


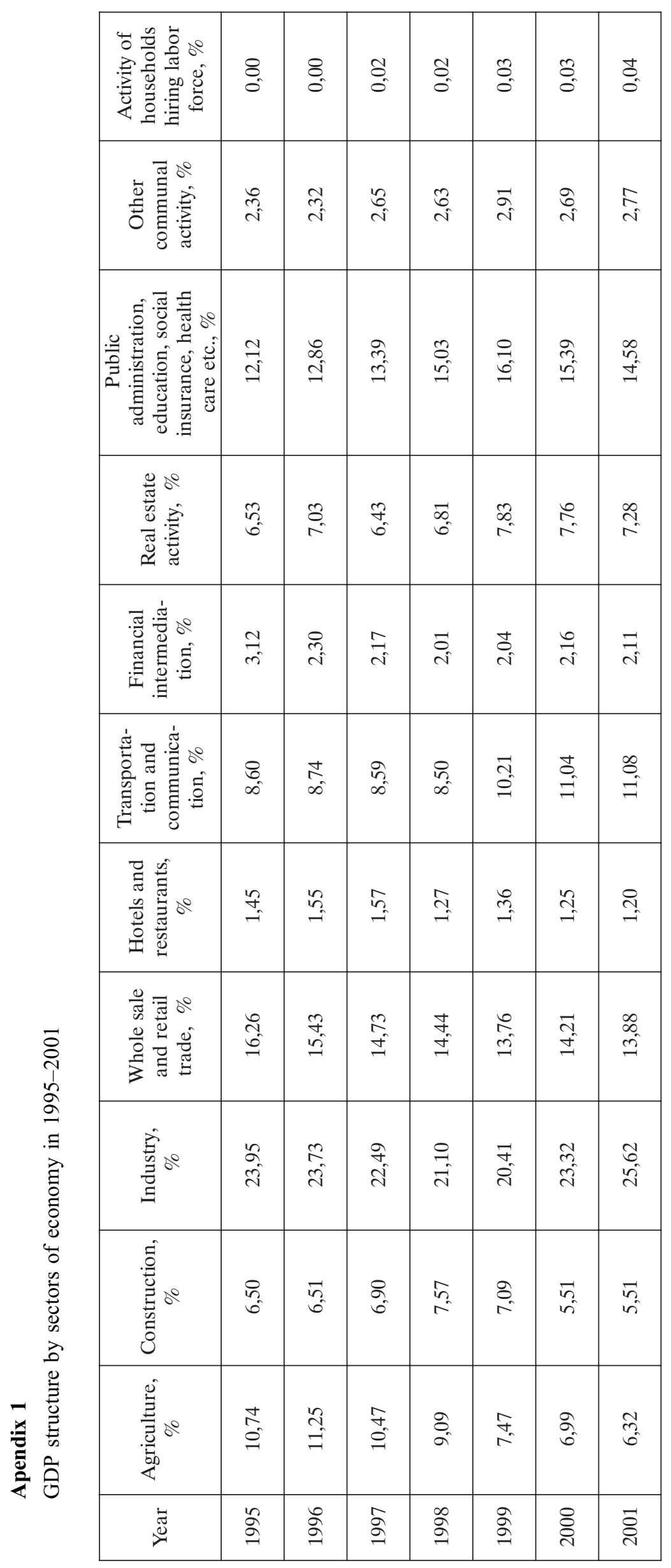




\begin{tabular}{|c|c|c|c|c|c|c|c|c|c|c|c|}
\hline 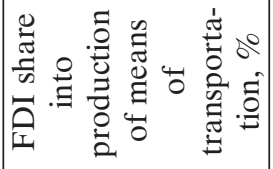 & 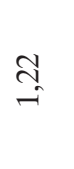 & $\underset{m}{\stackrel{J}{m}}$ & 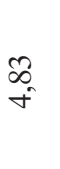 & $\stackrel{m}{m}$ & 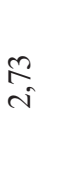 & $\underset{i}{\stackrel{2}{0}}$ & $\stackrel{f}{\rightarrow}$ & 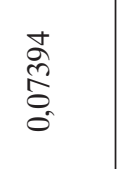 & $\begin{array}{l}\bar{\sigma} \\
\text { : } \\
0 \\
0\end{array}$ & $\begin{array}{l}1 \\
0 \\
0 \\
\vdots \\
0\end{array}$ & 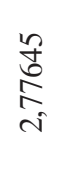 \\
\hline 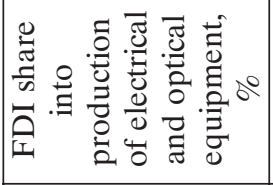 & $\begin{array}{l}\stackrel{8}{*} \\
\leftarrow\end{array}$ & $\underset{m}{\infty}$ & $\underset{\sim}{\stackrel{8}{m}}$ & $\stackrel{\text { bo }}{i}$ & $\vec{i}$ & $\begin{array}{c}\hat{i} \\
\hat{i}\end{array}$ & $\stackrel{\text { s. }}{i}$ & 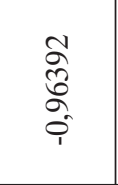 & $\begin{array}{l}\stackrel{8}{0} \\
\stackrel{0}{\Xi} \\
\stackrel{0}{0}\end{array}$ & 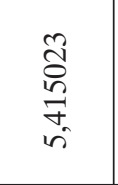 & \\
\hline 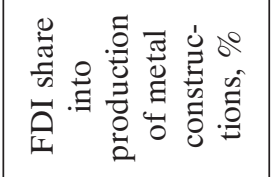 & $\begin{array}{l}\infty \\
\text { n? }\end{array}$ & $\begin{array}{l}n \\
\text { nn } \\
0\end{array}$ & के & $\stackrel{f}{8}$ & $\stackrel{\text { fos }}{\sigma}$ & in & $\stackrel{8}{0}$ & $\begin{array}{l}\vec{n} \\
0 \\
o \\
0 \\
\stackrel{+}{1}\end{array}$ & 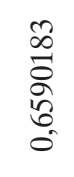 & 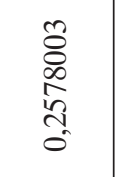 & \\
\hline 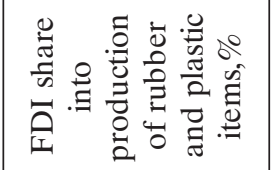 & $\begin{array}{l}n \\
\text { in } \\
\text { in }\end{array}$ & 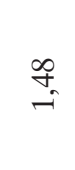 & 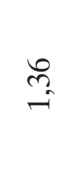 & $\underset{\sim}{\stackrel{\infty}{\sim}}$ & $\cong$ & $\stackrel{ \pm}{=}$ & $\underset{-}{\sigma}$ & $\begin{array}{l}\text { 孛 } \\
\text { Бे } \\
\hat{i}\end{array}$ & 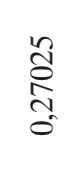 & $\begin{array}{l}n \\
b \\
\infty \\
\infty \\
m \\
m\end{array}$ & \\
\hline 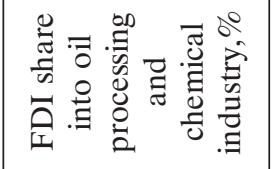 & fo & $\stackrel{\text { of }}{i}$ & $\stackrel{\infty}{\stackrel{\infty}{\sim}}$ & $\underset{m}{ \pm}$ & $\underset{6}{6}$ & $\underset{-\infty}{\infty}$ & $\begin{array}{c}\text { Do } \\
0 \\
0\end{array}$ & $\begin{array}{l}\text { Na } \\
= \\
\cdots \\
3\end{array}$ & 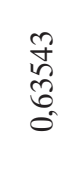 & $\begin{array}{l}\text { के } \\
\text { वें } \\
\stackrel{0}{+} \\
0\end{array}$ & \\
\hline 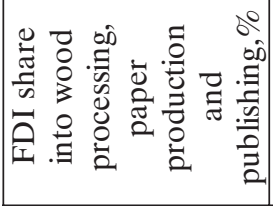 & $\stackrel{l}{\text { fo }}$ & $\stackrel{\vec{f}}{\vec{f}}$ & $\stackrel{0}{i}$ & $\underset{\text { I }}{\text { s }}$ & ल⿸户 & $\underset{\text { gे }}{\text { gे }}$ & 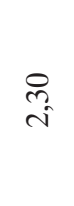 & $\begin{array}{l}0 \\
0 \\
\infty \\
\vec{\pi} \\
0 \\
0 \\
1\end{array}$ & $\begin{array}{l}\frac{0}{\infty} \\
\frac{2}{0} \\
\frac{1}{2} \\
0 \\
0\end{array}$ & 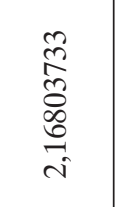 & \\
\hline 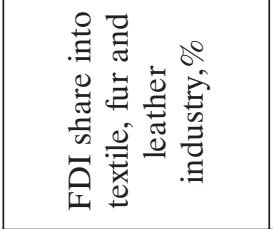 & fُ & $\underset{\sigma}{\sigma}$ & $\stackrel{\sim}{\sim}$ & $\begin{array}{l}\vec{\infty} \\
\stackrel{+}{*}\end{array}$ & $\stackrel{m}{\stackrel{m}{*}}$ & $\begin{array}{l}\hat{6} \\
\stackrel{f}{*}\end{array}$ & 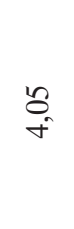 & $\begin{array}{l}\hat{n} \\
\hat{\sigma} \\
\text { ले } \\
\infty \\
0 \\
0\end{array}$ & 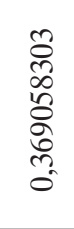 & 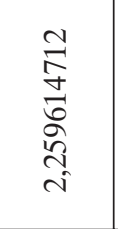 & \\
\hline 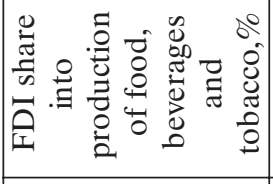 & $\begin{array}{l}\stackrel{n}{n} \\
\stackrel{2}{n}\end{array}$ & $\underset{0}{ \pm}$ & $\begin{array}{l}\text { ले } \\
\stackrel{2}{n}\end{array}$ & $\stackrel{?}{\stackrel{2}{=}}$ & $\begin{array}{l}\infty \\
= \\
=\end{array}$ & $\begin{array}{l}\stackrel{\text { 点 }}{=}\end{array}$ & \begin{tabular}{l}
$\infty$ \\
$\infty$ \\
\hdashline
\end{tabular} & $\begin{array}{l}\infty \\
\stackrel{2}{ } \\
\stackrel{\circ}{i}\end{array}$ & $\begin{array}{l}\text { ते } \\
\text { Oे } \\
0\end{array}$ & $\begin{array}{l}\stackrel{2}{2} \\
\infty \\
? \\
0 \\
0\end{array}$ & \\
\hline 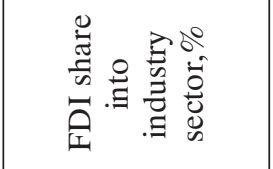 & $\begin{array}{l}\stackrel{m}{f} \\
f\end{array}$ & $\begin{array}{l}\tilde{F} \\
\vec{f}\end{array}$ & 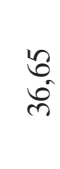 & $\begin{array}{l}F \\
\text { in }\end{array}$ & $\begin{array}{l}\text { ó } \\
\text { m }\end{array}$ & $\begin{array}{l}\vec{m} \\
\vec{m}\end{array}$ & $\begin{array}{l}\Delta \\
\stackrel{d}{d}\end{array}$ & $\begin{array}{l}\frac{n}{\hat{n}} \\
\stackrel{0}{0} \\
\hat{i}\end{array}$ & 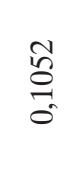 & 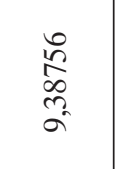 & \\
\hline 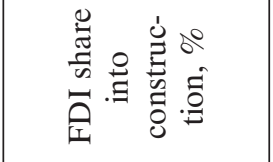 & $\stackrel{\infty}{\Rightarrow}$ & $\begin{array}{l}0 \\
\text { ñ. } \\
0\end{array}$ & ల్ & ?ח & $\stackrel{R}{R}$ & $\stackrel{n}{a}$ & $\stackrel{1}{0}$ & 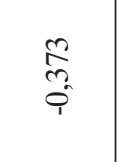 & 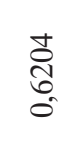 & $\overrightarrow{\tilde{B}}$ & \\
\hline 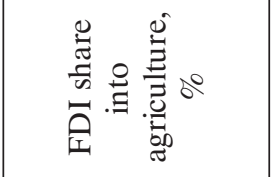 & $\underset{i}{\stackrel{8}{i}}$ & $\stackrel{8}{0}$ & $\stackrel{\infty}{=}$ & $\begin{array}{l}\infty \\
0 \\
0\end{array}$ & है & $\stackrel{\infty}{\stackrel{\infty}{0}}$ & f) & \begin{tabular}{l}
$\infty$ \\
\multirow{0}{+}{} \\
$\substack{0 \\
0 \\
i}$
\end{tabular} & $\begin{array}{l}\text { ô } \\
o \\
\infty \\
\infty \\
0 \\
0 \\
0\end{array}$ & $\begin{array}{l}1 \\
0 \\
0 \\
n \\
o \\
o \\
i\end{array}$ & \\
\hline 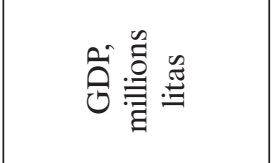 & $\begin{array}{l}8 \\
\infty \\
\mathbb{d} \\
\stackrel{d}{d}\end{array}$ & $\begin{array}{l}8 \\
\text { को } \\
0 \\
\stackrel{\circ}{m}\end{array}$ & 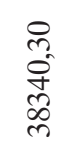 & $\begin{array}{l}8 \\
\text { बूँ } \\
\text { సे }\end{array}$ & \begin{tabular}{l}
8 \\
: \\
\multirow{0}{0}{} \\
\multirow{\sigma}{*}{}
\end{tabular} & $\begin{array}{l}8 \\
\stackrel{8}{0} \\
\dot{+} \\
\text { 学 }\end{array}$ & $\begin{array}{l}\text { ले } \\
2 \\
0 \\
2 \\
\hat{\sigma}\end{array}$ & \multirow{2}{*}{ 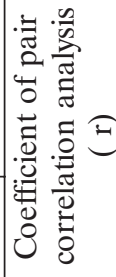 } & \multirow{2}{*}{ 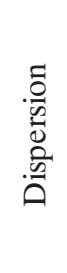 } & \multirow{2}{*}{ 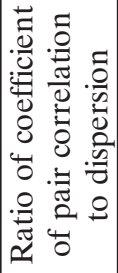 } & .0ّ \\
\hline$\stackrel{\bar{J}}{\bar{J}}$ & $\stackrel{\swarrow}{\sigma}$ & ஓ & $\hat{\sigma}$ & $\stackrel{\infty}{\circ}$ & ڤे & §ి & 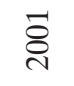 & & & & $\vec{E}$ \\
\hline
\end{tabular}




\begin{tabular}{|c|c|c|c|c|c|c|c|c|c|c|c|}
\hline 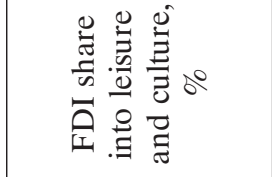 & 点 & ô. & $\stackrel{8}{:}$ & के & ñ & $\begin{array}{l}\text { ర్} \\
0\end{array}$ & $\begin{array}{l}\infty \\
\infty \\
0\end{array}$ & 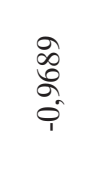 & 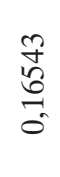 & $\begin{array}{l}n \\
\frac{n}{7} \\
0 \\
i n \\
i n\end{array}$ & $\begin{array}{l}\text { 告 } \\
\underset{i}{\hat{i}} \\
\text { in }\end{array}$ \\
\hline 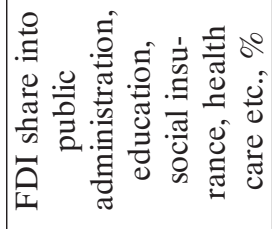 & $\stackrel{n}{\rightarrow}$ & $\vec{\sigma}$ & $\sqrt{n}$ & $\stackrel{\text { If }}{8}$ & m. & तै & 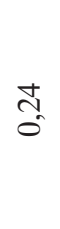 & $\begin{array}{l}n \\
\text { ते } \\
000 \\
0 \\
0 \\
0\end{array}$ & $\begin{array}{l}\hat{a} \\
\stackrel{+}{\mathbf{g}} \\
\stackrel{+}{0}\end{array}$ & 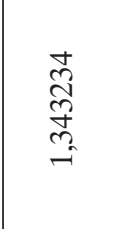 & \\
\hline 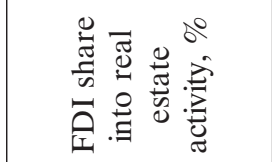 & $\stackrel{尺}{\approx}$ & $\stackrel{\Re}{=}$ & $\begin{array}{l}F \\
\forall\end{array}$ & $\begin{array}{c}\infty \\
\stackrel{m}{n}\end{array}$ & $\begin{array}{l}\infty \\
\stackrel{\infty}{n} \\
\text { nat }\end{array}$ & $\underset{i}{\stackrel{R}{i}}$ & $\begin{array}{l}\hat{\sim} \\
\stackrel{f}{*}\end{array}$ & 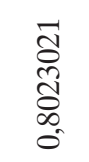 & $\begin{array}{l}\frac{1}{\infty} \\
\infty \\
\text { हूे } \\
0\end{array}$ & 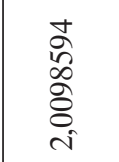 & \\
\hline 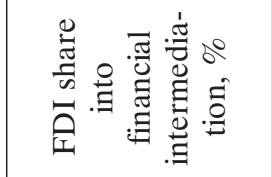 & $\frac{ \pm}{6}$ & $\begin{array}{l}\text { If } \\
n\end{array}$ & I & $\begin{array}{l}+ \\
\infty \\
\sigma_{0}\end{array}$ & $\begin{array}{l}\sqrt{6} \\
\stackrel{2}{\sigma}\end{array}$ & $\begin{array}{l}\text { స్ } \\
\text { }\end{array}$ & $\begin{array}{l}\infty \\
\text { - }\end{array}$ & $\begin{array}{l}\text { ôे } \\
\text { o. } \\
0\end{array}$ & 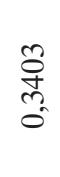 & $\begin{array}{l}\stackrel{\infty}{\hat{N}} \\
\text { in }\end{array}$ & \\
\hline 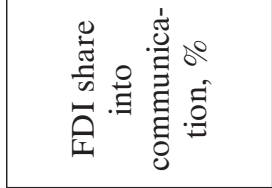 & $\underset{f}{\stackrel{J}{*}}$ & $\begin{array}{l}\text { ते } \\
\stackrel{9}{=}\end{array}$ & $\begin{array}{l}\text { in } \\
\text { of }\end{array}$ & $\stackrel{?}{\stackrel{f}{=}}$ & $\begin{array}{l}+ \\
\stackrel{\sigma}{\sigma}\end{array}$ & $\begin{array}{l}\infty \\
\infty \\
0 \\
0\end{array}$ & $\begin{array}{l}\stackrel{2}{2} \\
\underset{ \pm}{-}\end{array}$ & $\begin{array}{l}\hat{\hat{v}} \\
\stackrel{y}{2} \\
\stackrel{0}{0}\end{array}$ & 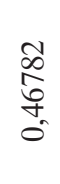 & 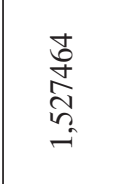 & \\
\hline 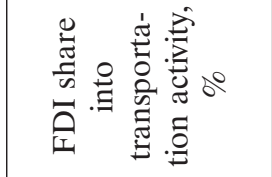 & $\stackrel{\text { m}}{\rightarrow}$ & $\begin{array}{l}\text { के } \\
0\end{array}$ & $\stackrel{+}{m}$ & $\stackrel{f}{\stackrel{m}{r}}$ & $\stackrel{\text { fos }}{i}$ & $\stackrel{\infty}{-}$ & $\begin{array}{l}8 \\
+\end{array}$ & 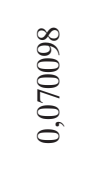 & $\begin{array}{l}n \\
0 \\
0 \\
0 \\
0 \\
0\end{array}$ & $\begin{array}{l}\infty \\
0 \\
0 \\
0 \\
0 \\
0\end{array}$ & \\
\hline 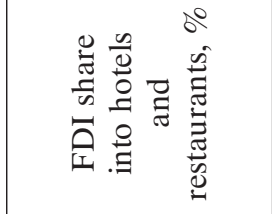 & $\stackrel{\infty}{\infty}$ & $\underset{\substack{\infty \\
i}}{\infty}$ & $\stackrel{\text { }}{\sigma}$ & $\stackrel{\infty}{-\infty}$ & $\begin{array}{l}n \\
\sim \\
i\end{array}$ & ते & $\stackrel{\vec{a}}{i}$ & $\begin{array}{l}\overrightarrow{\vec{J}} \\
0 \\
0 \\
0\end{array}$ & 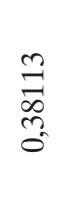 & $\begin{array}{l}\infty \\
0 \\
n \\
n \\
i\end{array}$ & \\
\hline 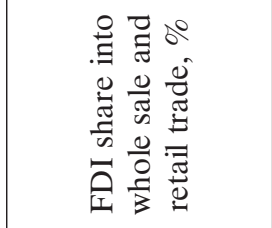 & $\begin{array}{l}\hat{m} \\
\ddot{n}\end{array}$ & $\begin{array}{l}\text { ñ } \\
\text { n̂. }\end{array}$ & $\begin{array}{l}\bar{\alpha} \\
\text { ते }\end{array}$ & $\begin{array}{l}\text { 을 } \\
\text { तो }\end{array}$ & \begin{tabular}{l}
$n$ \\
$\Re$ \\
\multirow{N}{*}{}
\end{tabular} & & $\stackrel{?}{\stackrel{\sim}{\sim}}$ & $\begin{array}{l}\widetilde{\alpha} \\
\text { Oू } \\
\text { o. }\end{array}$ & 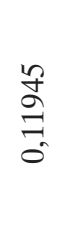 & $\begin{array}{l}\underset{\sim}{d} \\
\underset{n}{\infty} \\
\infty\end{array}$ & \\
\hline 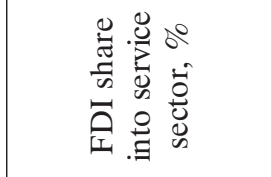 & \begin{tabular}{l}
2 \\
\multirow{\gamma}{\gamma}{}
\end{tabular} & $\begin{array}{l}\infty \\
\text { if } \\
\text { in }\end{array}$ & $\begin{array}{l}8 \\
\text { in }\end{array}$ & $\begin{array}{l}\bar{n} \\
\hat{b}\end{array}$ & $\begin{array}{l}n \\
n \\
\dot{b}\end{array}$ & $\begin{array}{l}\text { ț } \\
\text { గె }\end{array}$ & $\begin{array}{l}\stackrel{9}{q} \\
\text { so }\end{array}$ & $\begin{array}{l}0 \\
\infty \\
\infty \\
i \\
1\end{array}$ & 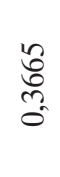 & $\begin{array}{l}\text { तु } \\
\text { Oे }\end{array}$ & \\
\hline 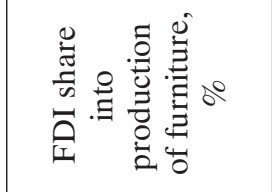 & $\begin{array}{l}\hat{\hat{n}} \\
\hat{n}\end{array}$ & જू & तै & సิ & $\begin{array}{l}\text { त̂ } \\
\text { on }\end{array}$ & 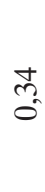 & m. & $\begin{array}{l}\infty \\
\stackrel{8}{o} \\
\stackrel{+}{\circ} \\
\stackrel{0}{1}\end{array}$ & 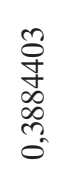 & 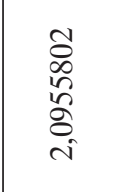 & \\
\hline 蛋 & \begin{tabular}{l}
$\infty$ \\
$\infty$ \\
i \\
\multirow{j}{*}{}
\end{tabular} & $\begin{array}{l}\text { a } \\
\text { ô } \\
\text { mे }\end{array}$ & 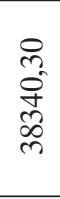 & $\begin{array}{l}8 \\
\text { \&े } \\
\text { ने }\end{array}$ & 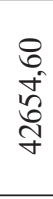 & $\begin{array}{l}\stackrel{\Xi}{\circ} \\
\stackrel{+}{+} \\
\text { g }\end{array}$ & $\begin{array}{l}\text { \% } \\
\infty \\
\swarrow \\
\hat{\alpha} \\
\gamma\end{array}$ & \multirow{2}{*}{ 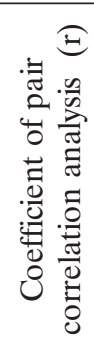 } & \multirow{2}{*}{ 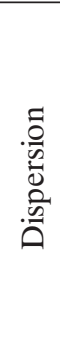 } & \multirow{2}{*}{ 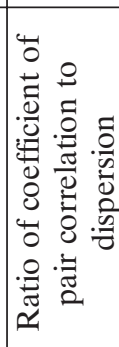 } & \multirow{2}{*}{ 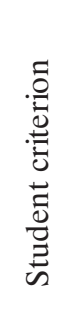 } \\
\hline$\underset{\nabla}{\tilde{D}}$ & $\stackrel{2}{2}$ & ஃ & ڤ్ & $\begin{array}{l}\infty \\
\stackrel{\sigma}{\sigma}\end{array}$ & बे & 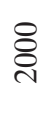 & ఠ్రి & & & & \\
\hline
\end{tabular}




\section{Appendix 3}

The biggest foreign investors in Lithuania [8]

\begin{tabular}{|c|c|c|c|c|c|}
\hline No. & The biggest investors in Lithuania & Country & Object & Economical activities & $\mathrm{m}_{€} \ln$. \\
\hline 1 & $\begin{array}{l}\text { Amber Teleholdings Consortium } \\
\text { (Telia/Sonera) }\end{array}$ & Sweden / Finland & Lietuvos Telekomas & Telecommunications & 835 \\
\hline 2 & $\begin{array}{l}\text { SEB-Skandinaviska Enskilda } \\
\text { Banken AB }\end{array}$ & Sweden & Vilniaus Bankas & Banking & 192 \\
\hline 3 & TDC (Tele Danmark A/S) & Denmark & Bitè GSM & Telecommunications & 151 \\
\hline 4 & Philip Morris International & USA & Philip Morris Lietuva & Tobacco Products & 84 \\
\hline 5 & $\begin{array}{l}\text { Carlsberg Breweries A/S; Baltic } \\
\text { Beverages Holding }\end{array}$ & $\begin{array}{l}\text { Sweden/ Finland/ } \\
\text { Denmark }\end{array}$ & Švyturys and Utena & Brewery & 78 \\
\hline 6 & Den Norske Stats Oljeselskap & Norway & Lietuva Statoil & Petroleum Products & 61 \\
\hline 7 & Hansapank A/S & Estonia & Hansabankas & Banking & 59 \\
\hline 8 & Vattenfall A/S & Sweden & Lietuvos Energija & $\begin{array}{l}\text { Energy Production and } \\
\text { Supply }\end{array}$ & 57 \\
\hline 9 & DFDS Tor Line A/S & Denmark & $\begin{array}{l}\text { Lithuanian Shipping } \\
\text { Company }\end{array}$ & Sea Transport & 125 \\
\hline 10 & Hansapank A/S & Estonia & LTB & Banking & 86 \\
\hline 11 & $\begin{array}{l}\text { Ruhrgas \& E.ON Energie } \\
\text { consortium }\end{array}$ & Germany & Lietuvos Dujos & Natural Gas & 63 \\
\hline 12 & $\begin{array}{l}\text { Bryggerigruppen (The Danish } \\
\text { Brewery Group) }\end{array}$ & Denmark & Kalnapilis & Brewery & 39 \\
\hline 13 & Dansico Sugar A/S & Denmark & Sugar Factories & Sugar Production & 39 \\
\hline 14 & $\begin{array}{l}\text { Amber Mobile Teleholding AB; } \\
\text { Motorola; Private Persons }\end{array}$ & $\begin{array}{l}\text { Sweden/ Finland/ } \\
\text { USA }\end{array}$ & Omnitel & Telecommunications & 38 \\
\hline 15 & The Coca-Cola Company & USA & $\begin{array}{l}\text { The Coca-Cola } \\
\text { Bottlers Lietuva }\end{array}$ & Soft Drinks & 36 \\
\hline 16 & Kraft Foods International & USA & Kraft Foods Lietuva & Confectionary \& Snacks & 36 \\
\hline 17 & Tele $2 \mathrm{AB}$ & Sweden & Tele 2 & Telecommunications & 35 \\
\hline 18 & Mars Inc. & USA & Masterfoods Lietuva & Pet Food & 31 \\
\hline 19 & Codan Insurance Ltd., A/S & Denmark & Lietuvos Draudimas & Insurance & 31 \\
\hline 20 & AS Hansa Liising & Estonia & Hanza Lizingas & Financial Services & 30 \\
\hline 21 & Euro Oil Invest S.A. & Luxembourg & Lukoil Baltija & Petroleum Products & 29 \\
\hline 22 & Neste OY & Finland & Neste Lietuva & Petroleum Products & 29 \\
\hline 23 & $\begin{array}{l}\text { Siemens Yazaki Wiring } \\
\text { Technologies GmbH }\end{array}$ & Germany / Japan & $\begin{array}{l}\text { Baltijos Automobilių } \\
\text { Technika }\end{array}$ & Electronics & 25 \\
\hline 24 & Shell Overseas Holdings Limited & $\begin{array}{l}\text { Great Britain / } \\
\text { Netherlands }\end{array}$ & Shell Lietuva & Petroleum Products & 23 \\
\hline 25 & $\begin{array}{l}\text { Partek Insulation; Finnfund; } \\
\text { NEFCO }\end{array}$ & Sweden / Finland & Partek Paroc & Construction Materials & 23 \\
\hline
\end{tabular}




\begin{tabular}{|c|c|c|c|c|c|}
\hline No. & The biggest investors in Lithuania & Country & Object & Economical activities & $\operatorname{mln}_{€}$ \\
\hline 26 & Farimex S.A., Profilo Holdings & Switzerland / Turkey & Ekranas & Electronics & 21 \\
\hline 27 & Odense Steel Shipyard Ltd & Denmark & Baltijos Laivų Statykla & Ship Building & 21 \\
\hline 28 & Baltic Fund One LT & USA & Baltic Fund Securities & Financial intermediation & 21 \\
\hline 29 & $\begin{array}{l}\text { NORD / LB (Norddeutsche } \\
\text { Landesbank Girozentrale) }\end{array}$ & Germany & LŽŪB & Banking & 40 \\
\hline 30 & $\begin{array}{l}\text { Osman Trading AB; Woodison } \\
\text { Trading AB; Ferrous Investment } \\
\text { Ltd.; Duboil Ltd. }\end{array}$ & $\begin{array}{l}\text { Sweden / Ireland / } \\
\text { Great Britain }\end{array}$ & Klaipeddos Nafta & Oil Terminal & 19 \\
\hline 31 & Tuch Fabrik Wilhelm Becker & Germany & Eurotextil & Textiles & 17 \\
\hline 32 & Svenska Petroleum Exploration $\mathrm{AB}$ & Sweden & Genčių Nafta & Oil Extraction & 17 \\
\hline 33 & AGA AB & Sweden & AGA & Trade in Gas & 17 \\
\hline 34 & Marzotto s.p.a. & Italy & Liteksas & Textiles & 13 \\
\hline 35 & Petrol Holding A/S & Norway & Pemco Kuras & Oil lubricants & 13 \\
\hline 36 & Danish Brewery Group & Denmark & Vilniaus Tauras & Brewery & 12 \\
\hline
\end{tabular}

